\title{
NGO Regulation: Themes and Debates with Reference to Nepal
}

\author{
Mukesh Kumar Bastola*
}

\begin{abstract}
Since the 1980s, due to the failure of previous development strategies, nongovernmental organizations have emerged as major actors in development, particularly in developing countries like Nepal. However, in recent years, most countries have perceived that NGOs are not operating genuinely to fulfill their expected goals. In this context, this paper set out to answer two questions: why $N G O s$ tend to represent donors' preferences and why developing countries like Nepal become unable to adopt strict NGO regulations. It is based on the analysis of archival documents and review of previous study findings and draws insights from resource dependence theory. It concludes that when NGOs depend on external donors for financial resources, they are compelled to represent donor's interests. Similarly, aid-dependent developing countries like Nepal often hesitate to adopt strict NGO regulations because of the fear of external pressure from their donor agencies. Thus, resource dependency makes both NGOs and the governments unable to resist the pressure of donor agencies. Its conclusions can be useful to adopt an appropriate framework to regulate NGOs in Nepal.
\end{abstract}

Keywords: Nongovernmental organizations, NGO regulations, resource dependence, donor agencies, Nepal

\section{Introduction}

Nongovernmental organizations (NGOs) are various private voluntary organizations operating outside the formal realms of government and private business (Haque, 2011). Since the late 1980s, NGOs have emerged as principal actors in development (Keese \& Argudo, 2006). In the mid-1990s, while government development efforts were perceived to have failed to deliver development outcomes to the poor in the developing world, NGOs' efforts were perceived to be successful (Barr, Fafchamps, \& Owens 2005). However, in recent years the growth of NGO activities have created regulatory challenges particularly for developing countries (Gugerty, 2008). Thus, both democratic and authoritarian regimes

* Mr. Mukesh Kumar Bastola is a lecturer at Public Administration Campus, Balkhu. Currently, he is pursuing a PhD in the NGO sector under the Faculty of Management, TU. 
have adopted restrictive regulations to impose barriers to NGOs (Glasius, Schalk, \& De Lange, 2020).

In Nepal, the rapid growth of the I/NGOs and their activities dates back to the early 1990s. The NGO movement was fueled by liberal policy and donor agencies to channel their development assistance though NGOs. Since the Eighth Plan (1992-1997), the government recognized NGOs as partners in national development and regarded them as a means of channeling development aid in the priority areas of the government (Ministry of Finance, 2019). Now, there is widespread suspicion regarding whether NGOs are genuinely operating their activities as expected by the government. So, the government has intended to adopt strict regulations to scrutinize NGOs. For instance, in 2017, the Ministry of Home Affairs (MoHA) issued a circular to District Administration Offices (DAOs) and Social Welfare Council (SWC) to seek details of the property of the executives and officials of NGOs and INGOs (Shrestha, 2019).

In April 2018, the government proposed a new policy titled "National Integrity Policy" to introduce strict measures to monitor NGOs. These measures created fears and controversy in the NGO sector. NGO practitioners and stakeholders opposed the move of the government (Shrestha, 2019). In 2018, the MoHA and the Ministry of Women and Social Welfare proposed to scrap the registration of NGOs and INGOs preaching religious beliefs and engaging in political activities and corruption (Giri, 2018). However, the government halted its proposed policy, and the MoHA backtracked from its previous directions to DAOs due to strong internal and external pressures, and lobbying from I/NGOs and activists.

The debate over NGO regulations still exists. The government authorities accuse NGOs of working against the national interests and threaten to take strong actions against them (Himalayan News Service, 2019). In contrast, I/NGOs, activists, and donors advocate for independence of NGOs to hold the government accountable to the society and to advocate alternative ideas. They view that the government should not control NGOs; instead should facilitate them (Human Rights Watch, 2019). They claim that if the government takes strict measures to prevent I/NGOs, it amounts to attacks on civil society and freedom of expression (Regmi, 2018). Recent skepticism and debate over NGOs has attracted genuine concerns over NGO regulations in Nepal.

Only few previous studies have explored the issues of NGO regulations and their impact on the NGO sector. A study by Barr, Fafchamps, and Owens (2005) in Uganda found that most NGOs were monitored by their grant agencies, some by members, and limited by the government.

Based on their study in Rwanda, Uganda, Kazakhstan, and Belarus, Christensen and Weinstein (2013) concluded that governments could adopt strategies to restrict the ability 
of NGOs to engage in political advocacy and mobilize foreign financial resources. The Ethiopia case study (Dietrich \& Wright, 2015) showed that NGOs operating in developing countries largely depended on external funding leading to the proliferation of sham NGOs serving as foreign agents. Similarly, Glasius, Schalk, and De Lange (2020) found that a country's willingness to adopt NGO restrictive legislation depends on authoritarian learning, perception of government authorities, potential pressures to the government, and domestic and international factors. Burger (2012) argues that government oversight mechanisms may be ineffective due to poor design, lack of adequate resources, and political motivation. If regulatory agencies are not motivated by social interests and oriented to make their stakeholders happy, NGO regulators serve particular interest groups.

Nepal is one of the aid-dependent countries, and INGOs are regarded as the primary funding sources for most Nepalese NGOs becasue 80 percent of NGOs operating in Nepal are funded by INGOs. In the fiscal year 2017/018, 140 INGOs affiliated with Association of International NGOs (AIN) brought US\$ 410 million to Nepal (Regmi, 2018). It is said that present NGO activities favor donors and INGOs, and such alleged skeptical NGO activities are primarily associated with the misuse of foreign financial resources. However, there is a dearth of studies to answer questions: why NGOs are loyal to donor agencies and are oriented to represent their interests, and why countries become unable to adopt strict NGO regulations. This paper draws on the theoretical perspective from resource dependence theory (Pfeffer \& Salancik, 2003) to address these questions.

\section{Conceptualization and Theoretical Framework}

\section{Conceptualization of NGOs}

NGOs are self-organized and self-regulated organizations independent of government and the private sphere (El-Gack, 2016). Although NGOs are nonprofit oriented social organizations (Martens, 2002), they often employ paid staff, serve the community at large, perform uncharitable functions, are affiliated to government agencies, and are regulated by a formal law of the state (Haque, 2011). They seek to provide services to marginalized groups (Dupuy, Ron, \& Prakash, 2015). They work at international, national, provincial, districts, and village levels (Heyzer, 1995). Domestic or local NGOs operate in a single country (Dupuy, Ron, \& Prakash, 2016). NGOs operating in several countries are known as INGOs (Karkee \& Comfort, 2016).

INGOs have the same mission as NGOs but they have an international scope (Ministry of Finance, 2018). INGOs have many professional staff, field offices in many countries (Bratton, 1989), and have a close link with national-level NGOs as local partners to implement their projects (Khieng, 2014). The conceptualization of NGOs depends on national contexts (Haque, 2011). The National Planning Commission [NPC] (1992) and the Association 
Registration Act [ARA] (1977) illustrate the attributes of NGOs as legal entities, voluntary or nonprofit making, autonomous, politically neutral, liberal in conducting programs, and oriented towards uplifting the poor and needy people (Ministry of Law, 1977). Since the understanding of NGOs is a contextual phenomenon, the definition by NPC (1992) and ARA (1977) seems more persuasive in the Nepalese context.

\section{Theoretical Framework}

The Resource dependence theory (RDT) propounded by Pfeffer and Salancik in 1970s , is one of the theoretical perspectives to explain how organizations operate, react to interdependence, and uncertainty in the environment (Hillman, Withers, \& Collins, 2009). The theory explains the relationship between organizations and their resource providers (Ebrahim, 2003). Based on their previous seminal work (1978), Pfeffer and Salancik (2003) postulate three themes of RDT. First, if we want to understand the organizational actions, it is necessary to focus on external situations and pressures instead of their internal dynamics. Second, when organizations alter their environment, they are subject to different constraints leading to further negotiation. Third, power is essential for understanding organizations. Some organizations are more powerful than others due to their peculiarities of interdependence and location.

According to RDT, similar to other organizations, NGOs are also subject to external control due to resource dependency. In such cases, NGOs are compelled to adopt business-oriented activities, modify their goals, and manipulate their programs to satisfy donor agencies leading to organizational goal displacement (Khieng, 2014). When NGOs depend on external financial sources for their survival, their choices and operations are bound by external pressures (Verbruggen, Christiaens, \& Milis, 2011). The dependency on donor agencies for funding ultimately threatens the identity, autonomy, and legitimacy of NGOs. Resource asymmetry between donors and dependent NGOs results in organizational subservience and makes them vulnerable to external control (Mitchell, 2014).

The RDT also provides a theoretical perspective to explain the behaviors of the government towards NGOs and NGOs' behaviors towards donors (Verbruggen, Christiaens, \& Milis, 2011). Its central argument is that if we want to understand organizational activities, we must understand their surroundings (Hillman, Withers, \& Collins, 2009) because the survival of organizations becomes problematic due to uncertain environmental situations, particularly lack of adequate and stable resources (Froelich, 1999). Thus, this paper assumes that resource dependence makes both the government and NGOs unable to resist pressures from their resource providers. 


\section{Methods}

This paper employs content analysis of secondary souces including archival documents (Brown \& Hale, 2014) historical documents, publications of government agencies and NGOs, and newspaper and media records. It also draws insights form the review of relavant literatureto gain the broader understanding of the phenomena under study. Based on the analysis and review, themes are derived to answer the researh questions.

\section{Analysis and Results}

Research Question 1: Why do NGOs tend to represent donors' preferences instead of their beneficiaries?

\section{International Funding and NGOs}

In the 1970s, development aid agencies realized the failure of traditional development strategies to deal with social problems in developing countries (Midgley, 2003). Donor agencies realized the resource constraints in developing countries. They regarded NGOs as a new policy option to channel their financial resources to assist developing countries instead of government agencies (Burger, Dasgupta, \& Owens, 2015; Dupuy, Ron, \& Prakash, 2016). Foreign development assistance is the primary source of funding for developing countries, contributing about 10 percent of their GDP. One-fifth of total bilateral development aid from developed countries to developing countries is channeled through NGOs (K. Dupuy \& Prakash, 2018).

NGOs operating in developing countries primarily seek to obtain financial resources from foreign donors and INGOs (Dupuy, Ron, \& Prakash, 2016). For instance, in Uganda, about 71 percent of total funding for NGOs was granted from bilateral donors and INGOs (Barr, Fafchamps, \& Owens, 2005). In Cambodia, foreign grants and donations were the dominant sources of funding for NGOs and only one-fifth of the NGOs were engaged in income-generating activities (Khieng, 2014). It is worth noting that there is an interdependence between donors and domestic NGOs. Donors are dependent on domestic NGOs to implement their programs, and domestic NGOs depend on donors for financial and technical support for their operations (Khieng, 2014). They regard NGOs as a pillar of democracy and promote them in developing countries (Dupuy \& Prakash, 2018). Donor agencies often provide two types of assistance: "economic aid and democracy assistance" (Dietrich \& Wright, 2015, p. 217). The former is intended for political reform and the latter aims to strengthen civil society. Donor agencies mostly tend to link their development assistance to democracy in developing countries.

Foreign development assistance have different implications to aid recipient countries. External funding usually comes with specific terms and conditions, which often negatively 
impacts the mission and goals of beneficiary NGOs (Khieng, 2014). Although foreignfunded NGOs may not directly challenge government political matters, their resources are accused of gradually empowering NGOs as political opponents (Dupuy, Ron, \& Prakash, 2016). Sometimes, donor agencies may use their financial aid to political reform as the condition of their aid package (Dietrich \& Wright, 2015). In this regard, Dietrich (2013) argues that if aid recipient countries' governance quality is poor, donor agencies bypass government and channel development aid through NGOs.

NGOs, like other organizations, are not entirely independent, and their success depends on their ability to acquire and maintain resources (Pfeffer \& Salancik, 2003). Most of the NGO projects in developing countries like Nepal are the projects of external donors and INGOs. However, when NGOs are heavily dependent on external donor agencies for financial resources to implement their programs, their survival becomes problematic when resource providers do not support them (Khieng, 2014). Their choices and operations are bound by external pressures (Verbruggen, Christiaens, \& Milis, 2011). More precisely, the need for physical, financial, and other resources from the environment make organizations depend on the resource providers (Pfeffer \& Salancik, 2003). As a result, NGOs' financial dependency on external funding agencies leads NGOs to detach themselves from their local constituencies and beneficiaries and tend to serve the preferences of resource providers (Dupuy, Ron, \& Prakash, 2014). Studies on NGOs and their resource dependence reveal their contracting relationships with donors, high resource asymmetry, and external control (Mitchell, 2014). From resource dependence literature, NGOs become vulnerable to resist the donors' terms and conditions and show their loyalty towards them.

Research Question 2: Why do developing countries like Nepal become unable to adopt strict NGO regulations?

\section{A Framework for NGO Regulation}

Regulation of NGOs in both developed and developing counties become problematic because NGOs typically do not charge total cost of their services to the beneficiaries (Barr, Fafchamps, \& Owens, 2005). Due to the voluntary nature, enforcement of rules becomes more complex, impeding the effectiveness of regulating NGOs (Burger, 2012; Burger, Dasgupta, \& Owens, 2015). Besides, the engagement of NGOs in political matters in developing countries may enable them to engage in corruption and misuse of financial resources (Islam \& Morgan 2012). When regulatoy mechanisms and government oversights are weak; and foreign funds are readily available, it opens the door for corrupt NGO activities, destroys the NGO sector (Clark, 1995), and proliferates fake and briefcase NGOs (Dupuy, Ron, \& Prakash, 2015). Nevertheless, NGO regulation is vital to ensure public confidence and contribute to the robust NGO sector (Barr, Fafchamps, \& Owens, 2005) by encouraging wise behaviors, discouraging corruption, and minimizing the negative 
externalities (Burger, 2012). Gugerty, Sidel, and Bies (2010) classify NGO regulations into two categories: voluntary and non-voluntary regulations. Specifically, there are four forms of NGO regulation documented in the literature: government regulation, self-regulation, donor monitoring, and community participation (Burger, 2012).

\section{Government Regulation}

Government regulation over NGOs has been a global phenomenon. Although government agencies have primary roles in regulating NGOs, they face difficulties in adopting appropriate mechanisms to handle them (Gugerty, Sidel, \& Bies, 2010). Government regulation has been criticized becasue strict government scrutiny may force NGOs to divert their productive financial resources from development to unproductive administrative activities (Burger, Dasgupta, \& Owens, 2015). Likewise, the regulatory power with politicians and bureaucrats allows NGOs to engage in corruption and politics (Burger, Dasgupta, \& Owens, 2015). Government regulations may be ineffective due to the lack of proper design, adequate resources, capacity of the state, and political motivation (Burger, 2012).

\section{Self-Regulation}

The failure of governments to exercise their regulations over NGOs has led states to allow self-regulation (Gugerty, 2008). NGO self-regulation is a set of informal arrangements that serve as regulatory mechanisms to regulate NGOs (Gugerty, Sidel, \& Bies, 2010). African countries have adopted three types of NGO self-regulation: national self-regulatory guild, voluntary clubs, and voluntary codes of conduct (Gugerty, 2008). According to Gugerty (2008), under the national self-regulatory guild, the government delegates some regulatory authority to NGOs' umbrella organizations. The voluntary clubs consist of a collective of NGOs who adopt standards and mechanisms to regulate NGOs. The voluntary codes consist of national-level codes of conduct adopted by NGOs. Umbrella organizations of NGOs seek self-regulation (Gugerty, Sidel, \& Bies, 2010) through codes of conduct that offer several opportunities for NGOs to strengthen their better public image and accountability towards funding agencies and beneficiaries (Ebrahim, 2003). Self-regulation can serve as a complementary mechanism to government regulations.

\section{Donor Regulation}

Donor agencies often sponsor their programs through a set of standards required to comply with funding conditions (Gugerty, Sidel, \& Bies, 2010). They can either directly visit NGOs or screen their activities using various mechanisms (Barr, Fafchamps, \& Owens, 2005). They primarily focus on short-term and more measurable quantifiable results of NGO programs (Ebrahim, 2003) while utilizing their resources and results of development projects (Burger, 2012). It is assumed that donor agencies provide rewards for better- 
performing NGOs with more funds and they blacklist and cut funds to underperforming NGOs (Barr, Fafchamps, \& Owens, 2005).

Donor agencies typically conduct an external evaluation of NGO programs, particularly at the end of their projects, to gauge whether NGOs have achieved their expected goals (Ebrahim, 2003). Thus, they monitor the performance of the NGOs in terms of their accountability and effectiveness (Barr, Fafchamps, \& Owens, 2005). However, donors often face difficulties in obtaining reliable information to regulate NGOs. Due to lack of reliable information, they might not able to identify underperforming NGOs and continue to provide funds to them (Barr, Fafchamps, \& Owens, 2005). Donors' regulations, in many cases, may neglect the robustness of the NGO sector (Burger, 2012) and actual impacts of the NGO programs in society.

\section{Community Regulation}

Community regulation involves public meetings, hearings, surveys, social auditing, formal dialogues, and consultation of NGOs with community members in project-related activities (Ebrahim, 2003). Community members serve as the owner of development projects. So, they have incentives to monitor NGOs to fulfill their needs (Burger, 2012). The basic assumption is that community members are familiar with the local issues and have direct access to NGOs and their oversight over NGOs to promote their accountability towards beneficiaries (Ebrahim, 2003). However, since community members are just the recipients of NGO services, they are not empowered to regulate NGOs (Burger, 2012). They may have limited capacity to control NGOs and to hold them accountable to the society.

\section{The NGO Landscape and Regulation in Nepal}

Historically, traditional voluntary organizations' activities were part of Nepalese culture and were guided by social, cultural, and religious factors (Thapa \& Malla, 2002). Traditional voluntary activities were an essential component of development practices in Nepal (Neupane, 2002). The Rana regime (1846-1951) and the Panchayat system (19611990) did not allow the operation of social organizations. During the Panchayat period, only a few independent voluntary organizations and development-oriented NGOs were allowed to operate under strict government supervision and control (Bhatta, 2009). In the 1970s, the government introduced two important legal mechanisms: the Social Service National Coordination Council Act- 1977 (2034 BS) and the Associations Registration Act (ARA), 1977. In the early 1990s, it enacted the Social Welfare Act and established the Social Welfare Council in 1992 (2049 BS). Thus, the first democratic constitution (1990) paved the way for the mobilization of NGOs to fulfill the state's guiding principles, which, in turn, led to the liberalization of NGO legislation in Nepal (Bhattachan, 2004). 
The liberal policies and donors' interest to channel their development assistance contributed to an increase in the number of NGOs in the early 1990s significantly in line with the global trend ( Heaton $\square$ Shrestha 2004; Neupane 2002; Thapa \& Malla, 2002 ). As a result, the number of 250 NGOs before 1990 increased to 5976 in 1997 (Heaton $\square$ Shrestha, 2004). From 1977 to 2014, 39,759 NGOs and 189 INGOs were registered in Nepal (Karkee \& Comfort, 2016). As of June 2020, 50,398 NGOs are affiliated to the SWC (SWC, 2021). The government regulatory agencies in Nepal adopt a range of legal instruments to govern the NGOs. NGOs that seek to operate in Nepal are required to register at DAOs with the necessary information. They need to be affiliated to the SWC to approve their programs and mobilize foreign resources (Ministry of Law, 1992). At the local level, DAOs are the designated local government authorities to register, regulate, and monitor financial transactions and operational activities of NGOs. If any NGO embezzles resources and abuses authority, DAOs take legal actions against such NGOs (World Bank, 2003). Under ARA (1977), DAOs have the authority to suspend NGOs if their activities are against NGOs' objectives.

NGOs and INGOs seeking to carry out programs should submit project proposals to SWC with details of partners, plans, programs, and funding arrangements (Ministry of Law, 1992). After adopting the federal structure in 2015, the government enacted the 'Local Government Operation Act' in 2016, which provides authority to municipalities to mobilize NGOs at the local level. The development cooperation policy clearly states that N/INGOs cannot mobilize external development funds religious and political purposes and against national needs, interests, and priorities (Ministry of Finance, 2019).Similarly, government NGO regulations recognize local NGOs as distinct from INGOs and treat them differently under the same legal framework.

Nepal has largely depended on foreign aid agencies and INGOs for its development for more than six decades (Karkee \& Comfort, 2016). INGOs are significantly contributing to virtually all sectors and are engaged in almost all districts of the country. The figure shows that while in the fiscal year 2017/18, INGOs disbursed US\$ 81 million in the social welfare programs, the figure rose to US\$ 215 in the fiscal year 2018/2019 (Ministry of Finance, 2018). The share of INGOs in official development assistance stands at 12 percent (Ministry of Finance, 2019). It is believed that international development assistance may influence political matters if resources are channeled through NGOs (Dupuy, Ron, \& Prakash, 2016). However, donor agencies prefer to to provide their assistance through NGOs than government (Christensen \& Weinstein, 2013) unless the government demonstrates its credibility, capacity, and willingness to utilize aid effectively (Dietrich, 2013).

The debates over NGO activities and government regulations have been genuine issues in Nepal. Mainly, aid-dependent countries like Nepal can be unable or reluctant to adopt strict NGO regulations. For instance, when the government prepared a draft for NGO 
in Cambodia, major INGOs put pressure on donors to rethink their development aid to Cambodia. Further, donors also urged the Cambodian government to reconsider its new law and threatened to halt their support which was the significant share of funding for the Cambodian government (Christensen \& Weinstein, 2013). Restrictions on foreign funding for NGOs can certainly be problematic for donors because it significantly undermines their strategies to channel development aid to developing countries (Dupuy \& Prakash, 2018). There is little empirical evidence that NGOs always operate altruistically and honestly because their interests may not necessarily be aligned with that of beneficiaries (Burger, 2012).

\section{Contemporary Trends}

Most countries adopted liberal policies to regulate NGOs until the mid-1990s. However, with the growth of NGOs, governments experienced deterioration in their regulatory capacities (Gugerty, 2008). There are growing pressures on governments and NGOs to develop a comprehensive regulatory framework in those countries where the NGO sector is growing and the government regulatory system is weak (Gugerty, Sidel, \& Bies, 2010). As a result, restrictive government regulation came into practice. Restrictive government regulations involve complex registration procedures, strict government oversights, restrictions in obtaining foreign funding, and government interventions in their operational activities (Gilbert, 2020). Since the mid-1990s, developing countries have also adopted strict regulations to control the capacity of NGOs to access foreign financial resources (Dupuy, Ron, \& Prakash, 2016). Restrictive NGO regulations got momentum gradually since the early 2000s (Glasius, Schalk \& De Lange, 2020), and most of the countries, even liberal democracies, are also adopting restrictive laws to control the operations and financial flows of INGOs (Dupuy, Ron, \& Prakash, 2015). At present, there is a growing trend to adopt restrictive measures against both NGOs and INGOs worldwide (Dupuy \& Prakash, 2018; Glasius, Schalk \& De Lange, 2020).

In this regard, a fundamental question has emerged: why do countries adopt restrictive NGO regulations? The extant literature presents two reasons underlying such restrictive regulations: domestic politics and international environment (Christensen \& Weinstein, 2013). First, governments adopt legal restrictions to respond to the threats observed in their political environment, and second, other states inspire them to adopt legal regulations against NGOs (Glasius, Schalk \& De Lange, 2020). When state authorities perceive NGOs as political agents posing a threat to the political system, they adopt strict regulatory mechanisms to control their activities, particularly activities of NGOs that mobilize external funds (Gilbert, 2020).

Various studies have indicated the growing trend of restrictive government regulation of NGOs throughout the world, although their data seem to suggest variations. For example, 
based on data from 98 countries, Christensen and Weinstein (2013) found that 20 countries have adopted restrictive regulations since 2002, and 51 countries either prohibited or restricted external funding for NGOs. A study by Dupuy, Ron, and Prakash (2015) showed that before 1994, 17 countries adopted restrictive laws to restrict INGOs' financial flows and operations. From 1995 to 2012, 69 countries adopted strict NGO regulations. By 2012, nearly 44 percent of countries in the world have adopted restrictive rules.

States primarily adopt strong regulatory mechanisms to restrict the availability of foreign financial resources to NGOs. For instance, since the mid-1990s, 39 countries have adopted restrictive laws to control foreign financial resources to NGOs (Dupuy \& Prakash, 2018). In 2011, government authorities in Egypt seized NGO offices. They were charged with receiving "unauthorized foreign funds and engaging in political activity" (Christensen \& Weinstein, 2013, p. 77). NGO regulation adopted in Russia in 2006 also created a variety of legal restrictions to NGOs (Gilbert, 2020). The law granted significant power to government authorities to scrutinize NGO activities. In 2012, Russia adopted new strict regulations targeting politically active NGOs receiving funds from foreign sources (Christensen \& Weinstein, 2013). Belarus enacted regulatory barriers to foreign-funded NGOs (Gilbert, 2020). African countries have also introduced legislation providing more authority to government agencies to monitor NGOs (Burger, 2012). The United Arab Emirates, Ecuador, and Zimbabwe have also adopted restrictive NGO regulations such as canceling licenses of INGOs working in democracy in UAE, banding foreign-funded programs in Ecuador and outlawing foreign-funded voter education programs in Zimbabwe (Christensen \& Weinstein, 2013). The evidence shows that restrictive NGO legislation is being targeted to those NGOs that operate against the national interests by mobilizing foreign funds.

The government is the critical institution to control the sources of funding, resource providers, and enforce rules (Verbruggen, Christiaens, \& Milis, 2011). For instance, Dupuy and Prakash (2018) analyzed the cases of 134 countries receiving aid from 1993 to 2012. They found that due to the adoption of restrictive regulations, there was a 32 percent decline in bilateral aid flows in such countries. Christensen and Scholars (2013) also claim that concerns over their aid effectiveness do not drive donors' aid policy because they do not usually pursue effective development strategies. Instead, aid tends to be used as a means to influence aid recipient countries to achieve their goals. Dietrich and Wright (2015) assert that donor agencies intend to promote democratic values and human rights norms through strengthening NGOs. Donor agencies take crackdown on NGOs negatively because they regard aid recipient countries as turning their backs on democracy. In this regard, the regulation of the NGO sector depends on the forms and sensitivity of the government. If the government is democratic, it provides incentives to NGOs to operate in the country and vice versa (Burger, 2012). Similarly, when the governments fear the potential pressure from donor agencies, they hesitate to adopt strict NGO regulations (Christensen \& Weinstein, 
2013). However, the effectiveness of international pressure depends on states' capacity to restrict pressure and relationships with donors.

\section{Concluding Remarks}

The purpose of this paper was to explain why NGOs tend to be loyal towards donors' preferences and why governments in developing countries can be reluctant to adopt strict NGO regulations. NGOs operating in developing countries like Nepal are primarily dependent on external donors agencies for their financial resources. Donors have their own interests which they want the beneficiary NGOs to comply with and even set explicit conditions for the same. External funding matters for NGOs for their survival. So, NGOs tend to represent the donors' interests in their programs and operations. Developing countries are also largely dependent on external donor agencies for development aid for their overall development. Governments adopt strict NGO regulations if they perceive that NGOs mobilize foreign funds against their national interests. However, aid dependent countries like Nepal may not adopt strict NGO regulations if they feel that donor agencies impose restrictions against them by cutting financial aid. Thus, if governments fear from the potential pressure from donor agencies, they hesitate to adopt strict NGO regulations.

In this situation, NGOs need to understand that resource dependence threatens their institutional identity. So they need to maintain operational independence with donors upon which they depend on funding. Similarly, NGO practitioners can mitigate resource dependence when they diversify in funding to sustain their organizations (Mitchell, 2014). Similarly, government legal restrictions need to be targeted to those NGOs operating against the national interests leaving others unaffected (Glasius, Schalk \& De Lange, 2020). Governments should protect and promote legitimate activities of genuine NGOs to achieve national development goals. Ethiopia's evidence also shows that the government enacted 'Charities and Societies Proclamation in 2009 that reshaped the number of NGOs. Due to restrictive regulation, NGOs heavily dependent on external funding disappeared, domestic NGOs were rebranded their activities and NGOs engaged in social welfare activities survived even after adopting the regulatory crackdown (Dupuy, Ron, \& Prakash, 2015).

Similarly, developing countries like Nepal should consider what Dietrich and Wright (2015, pp. 228-229) found in African countries over 20 years: "economic aid increases the chances of transition to multiparty politics but has little influence on the survival of multiparty politics." In a nutshell, this paper concludes that NGOs' dependency on donors compels them to be loyal towards donors' preferences and dependence of the government on external development assistance result in fear, vulnerability, and hesitation to adopt restrictive NGO regulations. This paper suggests developing a collaborative regulatory mechanism to tradeoff between four regulatory mechanisms typical to the Nepalese context to regulate NGOs and utilize their strengths to achieve national development goals. 


\section{References}

Barr, A., Fafchamps, M., \& Owens, T. (2005). The Governance of Non-Governmental Organizations in Uganda. World Development, 33(4), 657-679. https://doi. org/10.1016/j.worlddev.2004.09.010

Bhatta, C. D. (2009). The Rise and Fall of National Service in Nepal: A Critical Study of Service and Citizenship Building in Nepal (CSD Research Report No. 09-30; pp. 1-25). St . Louis. Retrieved from https://core.ac.uk/download/pdf/233215648.pdf

Bhattachan, K. B. (2004). NGOs in Nepal. In T. Gautam (Ed.), Non-Government Organizations: Challenges and Opportunities (pp. 65-96). Kathmandu: Sahakarya.

Bratton, M. (1989). The Politics of Government-NGO Relations in Africa. World Development, 17(4), 569-587.

Brown, M., \& Hale, K. (2014). Applied Research Methods in Public and Nonprofit Organizations (First edition). San Francisco, CA: Jossey-Bass.

Burger, R. (2012). Reconsidering the Case for Enhancing Accountability Via Regulation. VOLUNTAS: International Journal of Voluntary and Nonprofit Organizations, 23(1), 85-108. https://doi.org/10.1007/s11266-011-9238-9

Christensen, D., \& Weinstein, J. M. (2013). Defunding Dissent: Restrictions on Aid to NGOs. Journal of Democracy, 24(2), 77-91.

Clark, J. (1995). The State, Popular Participation, and the Voluntary Sector. World Development, 23(4), 593-601.

Dhakal, G. P. (2009). Partnership Between Local Governance and Civil Society in Nepal. Administrative Souvenir, 5(1), 1-10.

Dietrich, S. (2013). Bypass or Engage? Explaining Donor Delivery Tactics in Foreign Aid Allocation. International Studies Quarterly, 57, 698-712.

Dietrich, S., \& Wright, J. (2015). Foreign Aid Allocation Tactics and Democratic Change in Africa. The Journal of Politics, 77(1), 216-234. https://doi.org/10.1086/678976

Dupuy, K., Ron, J., \& Prakash, A. (2015). Who Survived? Ethiopia's Regulatory Crackdown on Foreign-Funded NGOs. Review of International Political Economy, 22(2), 419-456. https://doi.org/10.1080/09692290.2014.903854

Dupuy, K., \& Prakash, A. (2018). Do Donors Reduce Bilateral Aid to Countries With Restrictive NGO Laws? A Panel Study, 1993-2012. Nonprofit and Voluntary Sector Quarterly, 47(1), 89-106.

Dupuy, K., Ron, J., \& Prakash, A. (2016). Hands Off My Regime! Governments' Restrictions on Foreign Aid to Non-Governmental Organizations in Poor and Middle- 
Income Countries. World Development, 84, 299-311. https://doi.org/10.1016/j. worlddev.2016.02.001

Ebrahim, A. (2003). Accountability In Practice: Mechanisms for NGOs. World Development, 31(5), 813-829. https://doi.org/10.1016/S0305-750X(03)00014-7

El-Gack, N. (2016). The Power of Non-Governmental Organizations in Sudan: Do Structural Changes Matter? ARAS, 37(1), 52-72.

Froelich, K. A. (1999). Diversification of Revenue Strategies: Evolving Resource Dependence in Nonprofit Organizations. Nonprofit and Voluntary Sector Quarterly, 28(3), 246-268.

Gilbert, L. (2020). Regulating Society after the Color Revolutions: A Comparative Analysis of NGO Laws in Belarus, Russia, and Armenia. TThe Journal of Post-Soviet Democratization, 28(2), 305-332.

Giri, S. (2018, June 14). Government Outlines Measures to Monitor I/NGOs. The Kathmandu Post. Retrieved from https://kathmandupost.com/national/2018/06/14/ govt-outlines-measures-to-monitor-ingos

Glasius, M., Schalk, J., \& De Lange, M. (2020). Illiberal Norm Diffusion: How do Governments Learn to Restrict Nongovernmental Organizations? International Studies Quarterly, 64(2), 453-468.

Gugerty, M. K. (2008). The Effectiveness of NGO Self-Regulation: Theory and Evidence from Africa. Public Administration and Development, 28, 105-118.

Gugerty, M. K., Sidel, M., \& Bies, A. L. (2010). Introduction to Minisymposium: Nonprofit Self-Regulation in Comparative Perspective-Themes and Debates. Nonprofit and Voluntary Sector Quarterly, 39(6), 1027-1038. https://doi. org/10.1177/0899764010372971

Haque, M. S. (2011). Non-governmental Organizations. In M. Bevir (Ed.), The SAGE Handbook of Governance (pp. 330-341). London: SAGE Publications Ltd.

Heaton $\square$ Shrestha, C. (2004). The Ambiguities of Practising jat in 1990s Nepal: Elites, Caste and Everyday Life in Development NGOs. South Asia: Journal of South Asian Studies, 27(1), 39-63. https://doi.org/10.1080/1479027042000186423

Heyzer, N. (1995). Toward New Government- NGO Relations for Sustainable and People Centred Development. In N. Heyzer, J. V. Riker, \& A. B. Quizon (Eds.), Government-NGO Relations in Asia: Prospects and Challenges for People Centred Development (pp. 1-14). New York: Palgrave Macmillan.

Hillman, A. J., Withers, M. C., \& Collins, B. J. (2009). Resource Dependence Theory: A Review. Journal of Management, 35(6), 1404-1427. https://doi. org/10.1177/0149206309343469 
Himalayan News Service. (2019, May 6). Government to Regulate NGOs, Says Baskota. The Himalaya Times. Retrieved from https://thehimalayantimes.com/nepal/govtto-regulate-ngos-says-baskota

Human Rights Watch. (2019, November 14). Nepal: New NGO Law Should Protect Rights. Retrieved March 6, 2021, from Topic: Free Speech website: https://www.hrw.org/ news/2019/11/14/nepal-new-ngo-law-should-protect-rights

Islam, M. R., \& Morgan, W. J. (2012). Non-Governmental Organizations in Bangladesh: Their Contribution to Social Capital Development and Community Empowerment. Community Development Journal, 47(3), 369-385. https://doi.org/10.1093/cdj/ bsr024

Karkee, R., \& Comfort, J. (2016). NGOs, Foreign Aid, and Development in Nepal. Frontiers in Public Health, 4. https://doi.org/10.3389/fpubh.2016.00177

Keese, J. R., \& Argudo, M. F. (2006). Decentralisation and NGO-Municipal Government Collaboration in Ecuador. Development in Practice, 16(2), 114-127.

Khieng, S. (2014). Funding Mobilization Strategies of Nongovernmental Organizations in Cambodia. VOLUNTAS: International Journal of Voluntary and Nonprofit Organizations, 25(6), 1441-1464. https://doi.org/10.1007/s11266-013-9400-7

Martens, K. (2002). Mission Impossible? Defining Nongovernmental Organizations. Voluntas, 13(3), 271-285.

Midgley, J. (2003). Social Development: The Intellectual Heritage. Journal of International Development, 15(7), 831-844. https://doi.org/10.1002/jid.1038

Ministry of Finance. (2018). Development Cooperation Report (pp. 1-72). Kathmandu: Ministry of Finance.

Ministry of Finance. (2019). International Development Cooperation Policy, 2019. Ministry of Finance. Retrieved from https://mof.gov.np/uploads/document/file/ print_copy_IDCMP-2019_Eng-fullpage_20191107071739.pdf

Ministry of Law. (1977). Associations Registration Act, 1977. Government of Nepal. Retrieved from http://www.lawcommission.gov.np/en/

Ministry of Law. (1992). (The) Social Welfare Act, 1992: An Act relating to the Management of Social Welfare. Social Welfare Council. Retrieved from http://www.swc.org.np/ wp-content/uploads/2015/06/SWC-Act.pdf

Mitchell, G. E. (2014). Strategic Responses to Resource Dependence Among Transnational NGOs Registered in the United States. VOLUNTAS: International Journal of Voluntary and Nonprofit Organizations, 25(1), 67-91. https://doi.org/10.1007/ s11266-012-9329-2 
Neupane, B. D. (2002). Volunteerism in Nepal: A Perspective on the Existing Policies and Practices. In Volunteerism in Nepal (pp. 1-15). Kathmandu: National Planning Commission \& UN Volunteers Nepal.

NPC. (1992). The Eighth Plan (1992-1997) [Periodic Plan]. Kathmandu: National Planning Commission. Retrieved from National Planning Commission website: https:// www.npc.gov.np/en/category/periodic_plans

Pfeffer, J., \& Salancik, G. R. (2003). The External Control of Organizations: A Resource Dependence Perspective. California: Standford University.

Regmi, S. C. (2018, June 18). INGOs are Here to Complement the Government, Not to Challenge It. Retrieved from https://kathmandupost.com/interviews/2018/06/18/ ingos-are-here-to-complement-the-government-not-to-challenge-it

Shrestha, P. M. (2019, March 3). Non-Government Organizations Concerned Over a New Law to Regulate Them. The Kathmandu Post. Retrieved from https://kathmandupost. com/national/2019/11/03/non-government-organisations-concerned-over-a-newlaw-to-regulate-them

SWC. (2021). List of NGOs affiliated with SWC - Swc-Social Welfare Council Nepal. Retrieved May 2, 2020, from http://swc.org.np/list-of-ngos-affiliated-with-swc/

Thapa, L. C., \& Malla, U. N. (2002). Volunteerism and Promoting Voluntary Services. In Volunteerism in Nepal (pp. 16-26). Kathmandu: National Planning Commission \& UN Volunteers Nepal.

Verbruggen, S., Christiaens, J., \& Milis, K. (2011). Can Resource Dependence and Coercive Isomorphism Explain Nonprofit Organizations' Compliance With Reporting Standards? Nonprofit and Voluntary Sector Quarterly, 40(1), 5-32. https://doi. org/10.1177/0899764009355061 